\title{
Monitoring Heavy Metals Contamination in Yamuna River for its toxicity level in water, sediments and fish.
}

\author{
Rajeev Kumar ${ }^{1}$, A. K. Gupta ${ }^{1}$, R. M. Tripathi ${ }^{2}$, Amit Chattree ${ }^{3}$ \\ ${ }^{I}$ Department of Forensic Science Sam Higginbottom Institute of Agriculture, Technology \& Sciences, \\ (Deemed to-be- University) Allahabad (U.P.) India-211007 \\ ${ }^{2}$ Directorate of Forensic Science Services, MHA, Block no. 9, $8^{\text {th }}$ floor CGO Complex, New Delhi-110003, \\ India \\ ${ }^{3}$ Department of Chemistry Sam Higginbottom Institute of Agriculture, Technology \& Sciences, \\ (Deemed to-be- University) Allahabad (U.P.) India-211007
}

\begin{abstract}
The present works is carried out to monitor the concentrations of heavy metals in water sediments and fishes present in Yamuna River, with the view to evaluate and monitor the contamination in Yamuna river water and for public health issue. Water, sediments and fish samples were collected from different sites of Yamuna River in Allahabad. Metal contaminations in water showed significant correlation and seasonal variations with atmospheric deposition. The study revealed a positive metal contamination in Yamuna River, fishes and sediments for human health perspectives. The data revaled that, $\mathrm{Cu}$, and As although remained below their maximum permissible concentration but, levels of $\mathrm{Pb}$ and $\mathrm{Zn}$ in waters at six sites of river in Allahabad had higher than their maximum permissible concentrations.
\end{abstract}

Keywords: Heavy metals, water, fishes, sediments, Yamuna river.

\section{Introduction}

This study was conducted to ascertain the concentrations of lead, copper, arsenic, nickel and zinc in Yamuna river waters, sediments, and fish in order to assess the current threats to human health from heavy metal pollution, and also compared the current status with previous studies conducted in the River, there is a need to assess the concentrations of heavy metal pollution in the river waters, sediments, and fish can serve as a pointer for future actions (1).

Pollution of surface and ground waters from point and non-point sources are prevalent in most countries of the world. Rapid population growth, urbanization, intensive agricultural and industrial production, all gives rise to increased levels of emissions of organic and inorganic pollutants into the environment. In order to formulate laws that safeguard human health and the environment, it is necessary to understand the sources and quantities of various pollutants in the environment (2).

Measuring heavy metals in aquatic organisms may be a bioindicator of their impact on health of organism and ecosystem (3). The natural concentrations of these metals in water and tuna fish are very low and hence the risk of contamination in living tissue is not high. But Industrial effluent is one of the prime sources of metal contamination in river waters is no exception (4). lead, zinc, copper, arsenic and nickel are scavenged element with typical residence times and a profile of surface, concentration decreasing with depth. Lead an omnipresent pollutant finds its way into the sea through industrial waste water, discharged by industries such as printing, dyeing, oil refineries, etc. These heavy metals, being conservative in nature and have the maximum probability of biomagnifications, when they are transferred to the human beings through food chains of different tropic levels and in the marine food chain(5). With this background, edible fish samples were collected from Yamuna river in order to evaluate the degree of contamination and biomagnifications.

This study aimed to monitor the heavy metal contamination due to the sewage aquatic ecosystem. The main purpose of study was to obtain basic and simple information for a better understanding of environmental impact of some of the heavy metals contaminates the river and aquatic life. This information would be a useful tool for effective management and control of the Natural recourses.

\section{Study area}

\section{Methodology}

The river Yamuna was selected for monitoring the heavy metal concentration in water, sediment and fish organ samples during August 2011 to January 2012. The river has a mean depth of 4-5 mts. This water body receives the untreated sewage effluents from small scale industries, automobile wastes and surface runoff from the neighboring areas. The fishing activity established in the sewage fed, river has a great importance for the economic well being of locals and used for agriculture. In addition, the river water is being useful for irrigation of the nearby agricultural fields as well river beds in summer. 


\section{Sample collection, storage and analysis}

The overall approach concerned the collection, storage and analysis of metals in water, sediment and fish samples.

Water: Water samples were collected from $0.1 \mathrm{~m}$ below the water surface, into glass bottles that were pre cleaned by distilled water and acidified with concentrated $\mathrm{HNO}_{3}$ to $\mathrm{pH}$ less than 2.0, then stored at $4^{0} \mathrm{C}$ until the analysis. All water samples were immediately brought to the laboratory and were filtered through $0.45 \mu \mathrm{m}$ Millipore filters and acidified with concentrated $\mathrm{HNO}_{3}(1: 1 \mathrm{v} / \mathrm{v})$ per liter to $\mathrm{pH}$ less than 2.0 and analysis were performed as per slandered methods developed (6).

Sediment: The upper $10 \mathrm{~cm}$ of the bottom layer sediment was taken. Each sediment core was packed separately in acid-soaked clear polythene packets and brought to the laboratory in ice buckets. In the laboratory the sediment samples were dried at $105^{\circ} \mathrm{C}$ to constant weight, ground and the fraction and passing through a sieve Stored in clean acid-soaked polythene packets at $20^{\circ} \mathrm{C}$ till analysis were performed(6).

Fish: The Labeo rohita, which is consumed in larger group of local people, was selected to determine the heavy metal accumulation. Fish specimens were procured from the local fishermen, which were caught by gill nets. Fish samples were dried at $102^{\circ} \mathrm{C}$ to constant weight. The Internal organs of fishes, the muscle and gills were removed and digesting and cut into pieces and then were stored in polythene packet at $20^{\circ} \mathrm{C}$. Sample were acid digested, neutralized and collected.

Levels of heavy metals in all the samples were measured by Spectra AA 220G Atomic Absorption Spectroscopy (Varian GTA 110) at Geological Survey of India, Hyderabad. The minimum concentrations of metals that could be detected were $0.02 \mathrm{ppm}$ for each metal. Calibration was made with standard solutions. The precision and accuracy of determination was checked by repeated analysis of the sub samples of the available standards and by recovery tests.

\section{Statistical Analysis}

Heavy metal content determined in water and fish tissue sample were evaluated statistically using statistical analysis computer software. The metal value determined in water and fish tissues were normalized. The statistical analysis were determined as 0.05 .

\section{Result and Discussion}

Heavy metal concentration in water, sediments and sewage inlet drain of Yamuna River is present in Table 1. The levels of these metals in the water were in the order of lead followed by $\mathrm{Cu}, \mathrm{Zn}, \mathrm{Ni}, \mathrm{Pb}$.

The concentration of $\mathrm{Cu}$ ranged from 1.012 to $1.26 \mathrm{mg} / \mathrm{l}$ in water, while, in sediments deviated from 68.32 to $83.06 \mathrm{mg} / \mathrm{kg}$. The WHO guidelines for maximum permissible limit of copper in water is $0.05 \mathrm{mg} / \mathrm{l}$, the range obtained was higher than the WHO value; hence, adverse effect on health from domestic use are expected. DWAF issued guidelines for domestic water use at neutral or alkaline $\mathrm{pH}$, typical concentration of $\mathrm{Cu}$ in surface water should be $0.003 \mathrm{mg} / \mathrm{l}$ (7). The water is unsuitable for the maintenance of the aquatic ecosystem. However, $\mathrm{Cu}$ is not expected to cause any problem if the water is utilized for irrigation purposes.

Level of $\mathrm{Zn}$ in river water and sediment ranged between 0.29 to $0.89 \mathrm{mg} / 1$ and 0.036 to $0.028 \mathrm{mg} / \mathrm{kg}$, respectively. The WHO permissible limit of zinc is $0.10 \mathrm{mg} / \mathrm{l}$. Therefore, water is unsuitable for the sustenance of the aquatic life but could still be utilized for irrigation.

Levels of $\mathrm{Pb}$ in the water varied between 1.3 to $2.6 \mathrm{mg} / \mathrm{l}$ and between 1.32 to $2.68 \mathrm{mg} / \mathrm{kg}$ in sediments. The concentration of $\mathrm{Pb}$ obtained in sediment were higher than those in the river water, hence the sediment could be an influential factor to contribute the level of $\mathrm{Pb}$ in river water with other enhancing factors such as water $\mathrm{pH}$. Since acidic water is known to influence the solubility and availability of metals.

The WHO permissible limit for $\mathrm{Pb}$ in water is $0.05 \mathrm{mg} / \mathrm{l}$. the range obtained in this study exceeds the WHO standards hence, making the water unsuitable for domestic use and drinking. The use of the river water for drinking purpose by man and animals could lead to accumulate in biomagnifications process of the metal with resultant ill-health effects.

The concentration of Ni in river water ranged from 0.008 to $0.0093 \mathrm{mg} / \mathrm{l}$ and from 42.02 to $44.1 \mathrm{mg} / \mathrm{kg}$ in sediments. More attention has been focused on the toxicity of $\mathrm{Ni}$ in low concentration, such as the fact that $\mathrm{Ni}$ can cause allergic reactions and $\mathrm{Ni}$ compounds may be carcinogenic (8). The permissible limit for $\mathrm{Ni}$ is 0.05 $\mathrm{mg} / \mathrm{l}$, the range obtain in the study was much higher indicating that the water is highly contaminated. Among the known health related effects of $\mathrm{Ni}$ are skin allergies, lungs fibrosis, variable degrees of kidney and cardiovascular system poisoning. 
Forstner and Wittman (9) stated that there would be an interaction between water and sediments in terms of heavy metals. The release of metal ions to sediment is initiated by various mechanism and increase of salinity, low $\mathrm{pH}$, changes in redox conditions, microbial activity etc.

The accumulation of metals in the organs of fish is demonstrated in a better manner in Table 2, which gives the bio accumulation factors of different metals in gills and muscles of Labio Rhotia fish. The accumulation is most prominent for $\mathrm{Zn}, \mathrm{Cu}$ and $\mathrm{Ni}$ in muscle and gills of fish. However, edibility of the fish captured had the maximum accumulation in the gills. This is expected as gill functions as the primary filter for the river water consumed by this fish. Muscle show high accumulation of $\mathrm{Pb}$, occurrence of $\mathrm{Pb}$ in the organs should be instructive. This increases the risk of accumulation of these metals, including $\mathrm{Pb}$ in human body. It is prominent to note at this stage that $0.5 \mathrm{mg}$ per $100 \mathrm{~g}$ is the tolerance for $\mathrm{Pb}$ poisoning in human body (10).

Table 1: Elemental composition of water samples taken from 5 distinct places of Yamuna river along with their mean value and standard deviation.

\begin{tabular}{|c|c|c|c|c|c|c|c|}
\hline \multirow[t]{2}{*}{ S. No. } & \multirow[t]{2}{*}{ Metal } & \multicolumn{5}{|c|}{ Water (mg/l) } & \multirow[t]{2}{*}{ Mean } \\
\hline & & $\mathrm{W}_{1}$ & $\mathrm{~W}_{2}$ & $\mathrm{~W}_{3}$ & $\mathrm{~W}_{4}$ & $\mathrm{~W}_{5}$ & \\
\hline 1 & $\mathrm{Cu}$ & 19.36 & 12.09 & 15.33 & 23.31 & 18.13 & 17.64 \\
\hline 2 & $\mathrm{Zn}$ & 89.32 & 70.26 & 83.01 & 69.86 & 87.16 & 79.92 \\
\hline 3 & $\mathrm{Ni}$ & 6.89 & 4.01 & 8.19 & 2.08 & 7.42 & 5.71 \\
\hline 4 & $\mathrm{~Pb}$ & 14.16 & 19.36 & 14.02 & 16.79 & 12.01 & 15.26 \\
\hline
\end{tabular}

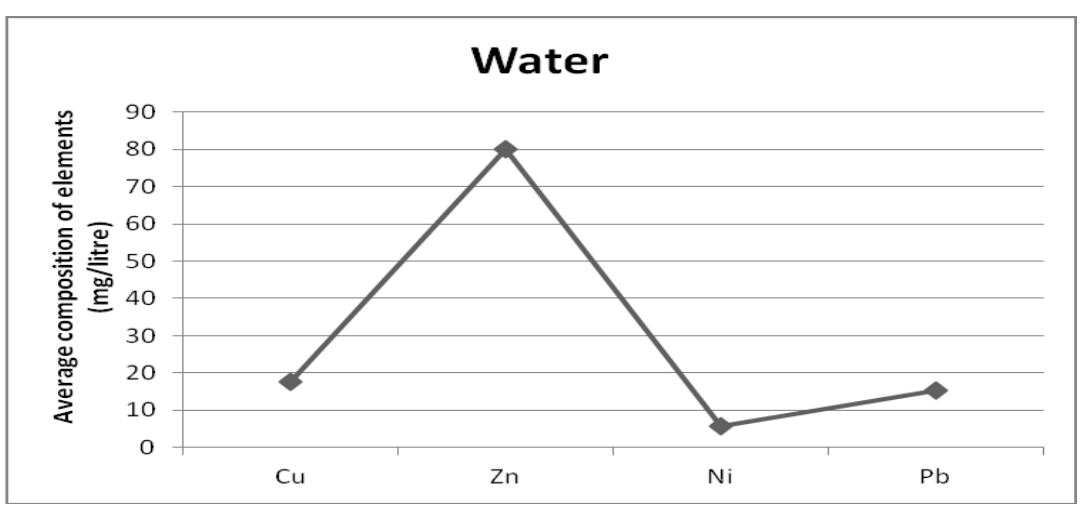

Figure-1 Graphical representation of average concentration of elements in water.

Table 2: Elemental composition of samples of sediment (in $\mathrm{mg} / \mathrm{kg}$ ) taken from 5 distinct places of Yamuna river along with their mean value and standard deviation.

\begin{tabular}{|l|l|l|l|l|l|l|l|}
\hline \multirow{2}{*}{ S. No. } & \multirow{2}{*}{ Metal } & \multicolumn{5}{|c|}{ Sediment (mg/kg) } & \multicolumn{2}{l|}{ Mean } \\
\cline { 3 - 8 } & & $\mathrm{S}_{1}$ & $\mathrm{~S}_{2}$ & $\mathrm{~S}_{3}$ & $\mathrm{~S}_{4}$ & $\mathrm{~S}_{5}$ \\
\hline 1 & $\mathrm{Cu}$ & 89.75 & 72.31 & 78.02 & 82.91 & 60.23 \\
\hline 2 & $\mathrm{Zn}$ & 0.034 & 0.029 & 0.011 & 0.039 & 0.032 & 0.029 \\
\hline 3 & $\mathrm{Ni}$ & 40.05 & 29.59 & 32.08 & 36.89 & 40.08 & 35.73 \\
\hline 4 & $\mathrm{~Pb}$ & 0.0189 & 0.0192 & 0.0159 & 0.0191 & 0.0184 & 0.0183 \\
\hline
\end{tabular}

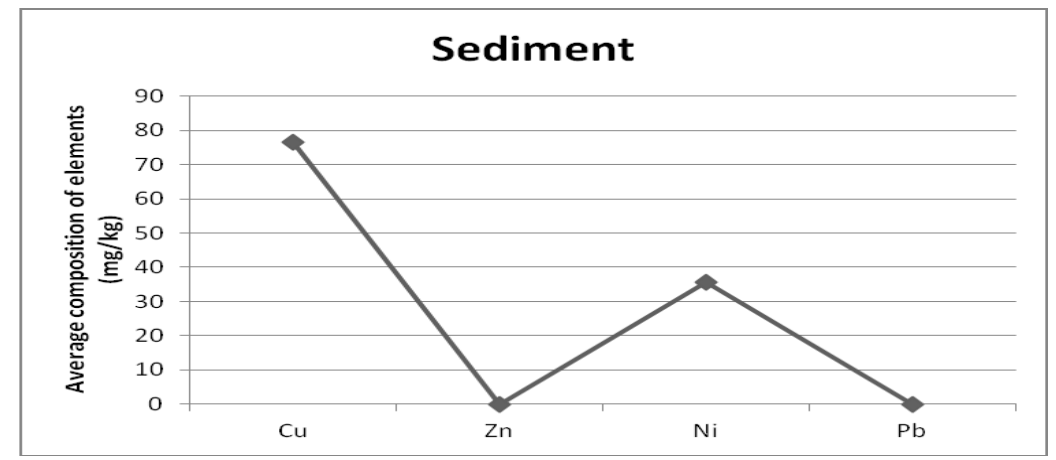

Figure-2 Graphical representation of average concentration of elements in water and sediments. 
Monitoring Heavy Metals Contamination in Yamuna River for its toxicity level in water, sediments

Table:-3 Heavy Metal Levels ( $\mu \mathrm{g} / \mathrm{g}$ dry weight) in fish organs of Labio rohita (Hamilton, 1822) from Yamuna river.

\begin{tabular}{|c|c|c|c|c|c|c|c|c|c|}
\hline & $\begin{array}{l}\text { Weight of } \\
\text { Fish } \\
\text { (g.) }\end{array}$ & \multicolumn{4}{|c|}{ Muscles } & \multicolumn{4}{|c|}{ Gills } \\
\hline & $\begin{array}{l}65.28 \\
70.3 \\
45.9 \\
78.32 \\
82.2\end{array}$ & $\begin{array}{l}5.32 \\
7.16 \\
6.23 \\
3.45 \\
7.16\end{array}$ & $\begin{array}{l}29.3 \\
32.1 \\
36.5 \\
34.15 \\
40.6\end{array}$ & $\begin{array}{l}1.37 \\
0.29 \\
0.16 \\
1.83 \\
0.46\end{array}$ & $\begin{array}{l}2.15 \\
6.64 \\
1.49 \\
5.72 \\
8.22\end{array}$ & $\begin{array}{l}3.62 \\
5.18 \\
3.08 \\
3.10 \\
3.09\end{array}$ & $\begin{array}{l}65.8 \\
53.22 \\
42.18 \\
68.9 \\
70.20\end{array}$ & $\begin{array}{l}0.32 \\
2.72 \\
0.27 \\
1.48 \\
2.62\end{array}$ & $\begin{array}{l}0.82 \\
0.39 \\
0.46 \\
0.19 \\
0.47\end{array}$ \\
\hline
\end{tabular}

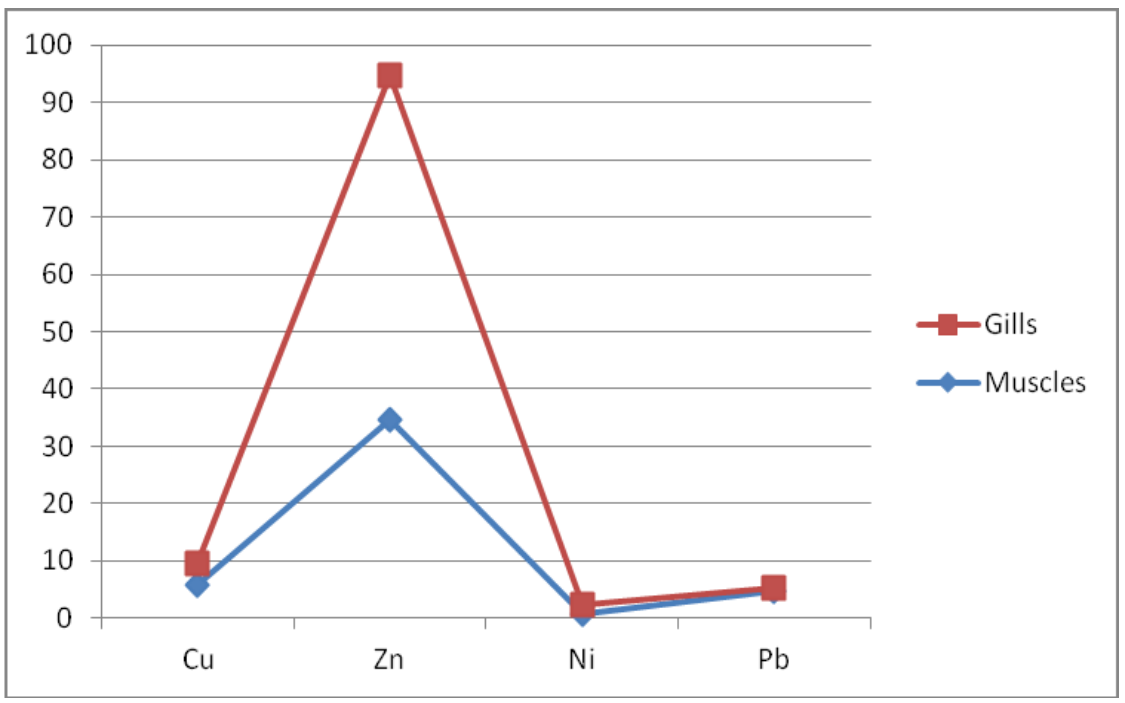

Figure-3 Graphical representation of average concentration of elements in gills and muscles.

The results of metals concentrations for water and fish samples obtained in this study were higher than the result for water and fish samples of Yamuna River. However, the concentrations of metals obtained in present investigation are comparable with metal ion concentrations in water of Yamuna River. The higher levels of trace metals in fish may result in toxic effects on human being after digestion. Therefore, aquatic animals of this river are surviving under stress condition of toxic metals.

\section{Correlation}

In water heavy metal, $\mathrm{Pb}$ shows significant positive correlation with $\mathrm{Zn}$. In fish organ i.e. muscle, heavy metal $\mathrm{Pb}$ shows significant positive correlation with $\mathrm{Zn}$ and $\mathrm{Ni}$ and highly significant positive relation with $\mathrm{Cu}$ whereas in Gills $\mathrm{Pb}$ shows highly significant positive correlation with $\mathrm{Cu}, \mathrm{Zn}$ and Ni

Table 4:- Pearson's correlation coefficient for fish organs and relevant water from Yamuna River where $G, M$ represents fish organs i.e. Gills, Muscles and $W$ represents water respectively.

\begin{tabular}{|c|c|c|c|c|c|c|c|c|c|c|c|c|c|c|c|}
\hline & $\begin{array}{l}\mathbf{W}_{1} \\
\mathbf{C u}\end{array}$ & $\begin{array}{l}\mathbf{W}_{2} \\
\mathbf{Z n}\end{array}$ & $\begin{array}{l}\mathbf{W}_{3} \\
\mathbf{N i}\end{array}$ & $\begin{array}{l}\mathbf{W}_{4} \\
\mathbf{P b}\end{array}$ & $W_{5}$ & $\begin{array}{l}\mathbf{M}_{1} \\
\mathbf{C u}\end{array}$ & $\begin{array}{l}\mathbf{M}_{2} \\
\mathbf{Z n}\end{array}$ & $\begin{array}{l}\mathbf{M}_{3} \\
\mathbf{N i}\end{array}$ & $\begin{array}{l}\mathbf{M}_{4} \\
\mathbf{P b}\end{array}$ & $\mathbf{M}_{5}$ & $\begin{array}{l}\mathbf{G}_{1} \\
\mathbf{C u}\end{array}$ & $\begin{array}{l}\mathbf{G}_{2} \\
\mathbf{Z n}\end{array}$ & $\begin{array}{l}\mathbf{G}_{3} \\
\mathbf{N i}\end{array}$ & $\begin{array}{l}\mathbf{G}_{4} \\
\mathbf{P b}\end{array}$ & $\mathbf{G}_{5}$ \\
\hline $\begin{array}{l}\mathbf{W}_{1} \mathbf{C} \\
u\end{array}$ & 1 & & & & & & & & & & & & & & \\
\hline $\begin{array}{l}\mathbf{W}_{2} \\
\mathbf{Z n}\end{array}$ & $\begin{array}{l}0.9 \\
86^{*}\end{array}$ & 1 & & & & & & & & & & & & & \\
\hline $\begin{array}{l}\mathrm{W}_{3} \\
\mathrm{Ni}\end{array}$ & $\begin{array}{l}0.9 \\
99^{*}\end{array}$ & $\begin{array}{r}0.98 \\
8 \\
\end{array}$ & 1 & & & & & & & & & & & & \\
\hline $\begin{array}{l}\mathbf{W}_{4} \\
\mathbf{P b}\end{array}$ & $\begin{array}{l}0.9 \\
85^{*}\end{array}$ & $\begin{array}{r}0.97 \\
6 \\
\end{array}$ & $\begin{array}{r}0.97 \\
6^{*}\end{array}$ & 1 & & & & & & & & & & & \\
\hline $\mathbf{W}_{5}$ & $\begin{array}{l}1.0 \\
00^{*}\end{array}$ & $\begin{array}{r}0.98 \\
2 \\
\end{array}$ & $\begin{array}{c}0.99 \\
9^{* * *} \\
\end{array}$ & $\begin{array}{r}0.98 \\
0^{*}\end{array}$ & 1 & & & & & & & & & & \\
\hline $\begin{array}{l}\mathbf{M}_{1} \\
\mathrm{Cu}\end{array}$ & $\begin{array}{l}0.9 \\
98^{*}\end{array}$ & $\begin{array}{r}0.97 \\
5 \\
\end{array}$ & $\begin{array}{c}0.99 * \\
7^{* *}\end{array}$ & $\begin{array}{r}0.97 \\
8^{*}\end{array}$ & $\begin{array}{c}0.99 \\
9^{* *}\end{array}$ & 1 & & & & & & & & & \\
\hline $\mathbf{M}_{2}$ & 0.9 & 0.99 & 0.99 & 0.99 & 0.99 & 0.98 & 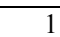 & & & & & & & & \\
\hline
\end{tabular}




\begin{tabular}{|c|c|c|c|c|c|c|c|c|c|c|c|c|c|c|}
\hline $\mathbf{Z n}$ & $94^{*}$ & $3^{* *}$ & $1^{* *}$ & $5^{* *}$ & $1^{* *}$ & $7^{*}$ & & & & & & & & \\
\hline $\begin{array}{l}\mathbf{M}_{3} \\
\mathbf{N i}\end{array}$ & $\begin{array}{l}0.9 \\
98^{*}\end{array}$ & $\begin{array}{r}0.97 \\
4^{*}\end{array}$ & $\begin{array}{c}0.99 \\
5 *\end{array}$ & $\begin{array}{r}0.98 \\
2^{*} \\
\end{array}$ & $\begin{array}{c}0.99 \\
9^{* * *}\end{array}$ & $\begin{array}{c}1.00 \\
0^{* *}\end{array}$ & $\begin{array}{r}0.98 \\
8^{*} \\
\end{array}$ & 1 & & & & & & \\
\hline $\begin{array}{l}\mathbf{M}_{4} \\
\mathbf{P b}\end{array}$ & $\begin{array}{l}0.9 \\
93^{*}\end{array}$ & $\begin{array}{r}0.99 \\
4^{* *}\end{array}$ & $\begin{array}{r}0.99 \\
7^{* *}\end{array}$ & $\begin{array}{r}0.96 \\
7^{*}\end{array}$ & $\begin{array}{r}0.99 \\
2^{* *}\end{array}$ & $\begin{array}{r}0.98 \\
8^{*}\end{array}$ & $\begin{array}{c}0.98 \\
8^{*}\end{array}$ & $\begin{array}{r}0.98 \\
5^{*}\end{array}$ & 1 & & & & & \\
\hline $\mathbf{M}_{5}$ & $\begin{array}{l}0.9 \\
94^{*}\end{array}$ & $\begin{array}{l}0.99 \\
7^{* *}\end{array}$ & $\begin{array}{l}0.99 \\
4^{* *}\end{array}$ & $\begin{array}{l}0.98 \\
8^{*}\end{array}$ & $\begin{array}{l}0.99 \\
1^{* *}\end{array}$ & $\begin{array}{l}0.98 \\
7^{*}\end{array}$ & $\begin{array}{l}0.99 \\
9^{* *}\end{array}$ & $\begin{array}{l}0.98 \\
7^{*}\end{array}$ & $\begin{array}{l}0.99 \\
4^{* *}\end{array}$ & 1 & & & & \\
\hline $\begin{array}{l}\mathbf{G}_{1} \\
\mathrm{Cu}\end{array}$ & $\begin{array}{l}0.9 \\
95^{*}\end{array}$ & $\begin{array}{r}0.97 \\
8^{*} \\
\end{array}$ & $\begin{array}{r}0.99 \\
8^{* *} \\
\end{array}$ & $\begin{array}{r}0.96 \\
3^{*} \\
\end{array}$ & $\begin{array}{r}0.99 \\
7^{* *} \\
\end{array}$ & $\begin{array}{c}0.99 \\
6^{* *}\end{array}$ & $\begin{array}{r}0.98 \\
1^{*} \\
\end{array}$ & $\begin{array}{r}0.99 \\
4^{* * *} \\
\end{array}$ & $\begin{array}{r}0.99 \\
4^{* * *} \\
\end{array}$ & $\begin{array}{r}0.98 \\
5^{*}\end{array}$ & 1 & & & \\
\hline $\begin{array}{l}\mathbf{G}_{\mathbf{2}} \\
\mathbf{Z n}\end{array}$ & $\begin{array}{l}0.9 \\
92^{*}\end{array}$ & $\begin{array}{r}0.96 \\
7^{*} \\
\end{array}$ & $\begin{array}{c}0.99 \\
4^{* *}\end{array}$ & $\begin{array}{r}0.95 \\
7^{*}\end{array}$ & $\begin{array}{c}0.99 \\
5^{* *}\end{array}$ & $\begin{array}{c}0.99 \\
6^{* *}\end{array}$ & $\begin{array}{r}0.97 \\
4^{*}\end{array}$ & $\begin{array}{r}0.99 \\
4^{* * *}\end{array}$ & $\begin{array}{r}0.98 \\
7^{*}\end{array}$ & $\begin{array}{r}0.97 \\
7^{*}\end{array}$ & $\begin{array}{c}0.99 \\
9^{* *}\end{array}$ & 1 & & \\
\hline $\begin{array}{l}\mathbf{G}_{3} \\
\mathbf{N i}\end{array}$ & $\begin{array}{l}0.9 \\
96^{*}\end{array}$ & $\begin{array}{r}0.97 \\
7^{*}\end{array}$ & $\begin{array}{c}0.99 \\
8^{* *}\end{array}$ & $\begin{array}{r}0.96 \\
6^{*}\end{array}$ & $\begin{array}{r}0.99 \\
8^{* * *}\end{array}$ & $\begin{array}{r}0.99 \\
8^{* *}\end{array}$ & $\begin{array}{r}0.98 \\
2^{*}\end{array}$ & $\begin{array}{r}0.99 \\
6^{* *}\end{array}$ & $\begin{array}{c}0.99 \\
2^{* *}\end{array}$ & $\begin{array}{r}0.98 \\
5^{*}\end{array}$ & $\begin{array}{c}1.00 \\
0^{* *}\end{array}$ & $\begin{array}{c}0.99 \\
9^{* *}\end{array}$ & 1 & \\
\hline $\begin{array}{l}\mathbf{G}_{4} \\
\mathrm{~Pb}\end{array}$ & $\begin{array}{l}0.9 \\
93^{*}\end{array}$ & $\begin{array}{r}0.97 \\
4^{*}\end{array}$ & $\begin{array}{c}0.99 \\
6^{* *}\end{array}$ & $\begin{array}{r}0.95 \\
6^{*}\end{array}$ & $\begin{array}{r}0.99 \\
5^{* *}\end{array}$ & $\begin{array}{r}0.99 \\
5^{* *}\end{array}$ & $\begin{array}{r}0.97 \\
5^{*}\end{array}$ & $\begin{array}{r}0.99 \\
2^{* * *}\end{array}$ & $\begin{array}{c}0.99 \\
2^{* *}\end{array}$ & $\begin{array}{r}0.98 \\
1^{*}\end{array}$ & $\begin{array}{c}1.00 \\
0^{* *}\end{array}$ & $\begin{array}{c}0.99 \\
9^{* *}\end{array}$ & $\begin{array}{r}0.99 \\
9^{* * *}\end{array}$ & 1 \\
\hline $\mathbf{M}_{5}$ & $\begin{array}{l}0.9 \\
91^{*}\end{array}$ & $\begin{array}{r}0.97 \\
2^{*}\end{array}$ & $\begin{array}{c}0.99 \\
5^{* *}\end{array}$ & $\begin{array}{r}0.95 \\
2^{*} \\
\end{array}$ & $\begin{array}{r}0.99 \\
4^{* *} \\
\end{array}$ & $\begin{array}{c}0.99 \\
3^{* *}\end{array}$ & $\begin{array}{r}0.97 \\
2^{*} \\
\end{array}$ & $\begin{array}{r}0.99 \\
0^{* * *} \\
\end{array}$ & $\begin{array}{r}0.99 \\
1^{* *} \\
\end{array}$ & $\begin{array}{r}0.97 \\
8^{*}\end{array}$ & $\begin{array}{r}0.99 \\
9^{* *}\end{array}$ & $\begin{array}{r}0.99 \\
9^{* * *} \\
\end{array}$ & $\begin{array}{r}0.99 \\
9^{* * *} \\
\end{array}$ & $\begin{array}{r}1.00 \\
0^{* * *}\end{array}$ \\
\hline
\end{tabular}

*Significant, ** Highly Significant,

W- Water, M-Muscle, G- Gills

Water $\mathrm{Pb}$ shows significance with water $\mathrm{Zn}$, Water $\mathrm{Ni}$, shows highly significant with Muscle $\mathrm{Cu}$ and also significant in muscle $\mathrm{Zn}$, Ni in Gills shows high significant with gills $\mathrm{Cu}, \mathrm{Zn}, \mathrm{Ni}$.

\section{Correlation Matrix}

Table 5:-Pearson's correlation coefficient for water and sediment from Yamuna river.

\begin{tabular}{|c|c|c|c|c|c|c|c|c|c|c|}
\hline & $\mathrm{W}_{1}$ & $\mathrm{~W}_{2}$ & $\mathrm{~W}_{3}$ & $\mathrm{~W}_{4}$ & $\mathrm{~W}_{5}$ & $S_{1}$ & $\mathrm{~S}_{2}$ & $\mathrm{~S}_{3}$ & $\mathrm{~S}_{4}$ & $\mathrm{~S}_{5}$ \\
\hline $\mathrm{W}_{1}$ & 1 & & & & & & & & & \\
\hline $\mathrm{W}_{2}$ & 0.986 & 1 & & & & & & & & \\
\hline $\mathrm{W}_{3}$ & $0.999^{* *}$ & $0.988^{2}$ & 1 & & & & & & & \\
\hline $\mathrm{W}_{4}$ & $0.985^{*}$ & $0.976^{\prime \prime}$ & 0.976 & 1 & & & & & & \\
\hline $\mathrm{W}_{5}$ & $1.000^{* *}$ & $0.982^{\prime \prime}$ & $0.999^{* *}$ & $0.980^{\circ}$ & 1 & & & & & \\
\hline $\mathrm{S}_{1}$ & $-0.449^{\mathrm{NS}}$ & $-0.572^{\mathrm{NS}}$ & $-0.488^{\mathrm{NS}}$ & $-0.390^{\mathrm{NS}}$ & $-0.442^{\mathrm{NS}}$ & 1 & & & & \\
\hline $\mathrm{S}_{2}$ & $-0.433^{\mathrm{NS}}$ & $-0.554^{\mathrm{NS}}$ & $-0.474^{\mathrm{NS}}$ & $-0.368^{\mathrm{NS}}$ & $-0.427^{\mathrm{NS}}$ & $0.999^{* * *}$ & 1 & & & \\
\hline $\mathrm{S}_{3}$ & $-0.434^{\mathrm{NSS}}$ & $-0.556^{\mathrm{NS}}$ & $-0.475^{\mathrm{NS}}$ & $-0.370^{\mathrm{NS}}$ & $-0.428^{\mathrm{NS}}$ & $0.999^{* *}$ & $1.000^{* * *}$ & 1 & & \\
\hline $\mathrm{S}_{4}$ & $-0.448^{\mathrm{NS}}$ & $-0.571^{\mathrm{NS}}$ & $-0.487^{\mathrm{NS}}$ & $-0.389^{\mathrm{NS}}$ & $-0.441^{\mathrm{NS}}$ & $1.000^{* *}$ & $0.999^{* * *}$ & $0.999^{* *}$ & 1 & \\
\hline $\mathrm{S}_{5}$ & $-0.524^{\mathrm{NS}}$ & $-0.653^{\mathrm{NS}}$ & $-0.554^{\mathrm{NS}}$ & $-0.500^{\mathrm{NS}}$ & $-0.512^{\mathrm{NS}}$ & 0.976 & $0.967^{\circ}$ & $0.967^{*}$ & 0.976 & \\
\hline
\end{tabular}

* Significant, ** Highly Significant, - Non significant- water, S- sediment

The concentration of $\mathrm{Pb}$ in aquatic animal may cause biomagnifications and adverse effect on human health of neighborhood. The presence of toxic elements $\mathrm{Cu}, \mathrm{Zn}, \mathrm{Ni}$ and $\mathrm{Pb}$ were higher beyond permissible limits in water and fishes which need special attention for safe guarding the health of common people.

\section{Conclusion:}

The study revaled that the heavy metal level were mainly corresponding to the natural background level except for $\mathrm{Pb}$ and $\mathrm{Ni}$ by increasing human activities in the Yamuna river increase heavy metal load. Trace element accumulation including toxic heavy metals in aquatic ecosystem as a whole is of great importance for the results of pollution level. Based on the results, the distribution of heavy metals in water, sediments and in fish indicated that the concentrations of these metals are derived from water with regular industrial and urban effluents which need to be checked and monitored. 


\section{References}

[1]. Malik A., Environmental International, 30, (2004), 261-278.

[2]. Eisenberg M. and Topping J.J. 1986. Trace metal residues in finfish from Maryland waters, 19781979. Journal of Environmental Science and Health, 21(1):87-102.

[3]. WHO, Guidelines for drinking water quality. (Vol. 5). World Health Organization, Geneva, Switzerland, 121, (1985).

[4]. Ashraf W., 2006. Levels of selected heavy metals in tuna fish. The Arab. J. Sci. Eng., 31(1A).

[5]. Zheljazkov V.D. and Nielson N.E., 1996. Effect of Heavy Metals on Peppermint and Cornmint. Plant Soil 178, 59-66

[6]. APHA, Standard methods for the examination of water and waste water, $20^{\text {th }}$ edition, APHA, AWWA \& WEF. N.W. Washington, D.C. (1998)

[7]. Department of Water affairs and Forestry, DWAF, Water quality guidelines, Domestic use.1 (2 $2^{\text {nd }} e d n$.) DWAF, Pretora (1996).

[8]. McKenzie H.A. and Smythe L.E. Quantitative trace analysis of biological materials, Elsevier, Amsterdam (1998).

[9]. Forstner U and Wittman G.T.U., Metal pollution methods for water pollution studies, Environ pobl. Karsd (MH), India: 238-240 (1986).

[10]. Patrick F.M. and Loutit M.W., Passage of metals of fresh water fish from their foods water Res., 12.P, 395 (1978). 